\title{
A instituição de ZEIS na legislação municipal: estudo de seis cidades médias de Minas Gerais
}

\author{
Isabelle Oliveira Soares
}

Arquiteta e Urbanista, mestranda do Programa de Pós-Graduação em Arquitetura e Urbanismo do Departamento de Arquitetura e Urbanismo da Universidade Federal de Viçosa, Universidade Federal de Viçosa, Centro de Ciências Exatas e Tecnológicas, Departamento de Arquitetura e Urbanismo, Campus UFV, CEP 36570-000, Viçosa, MG, isabelle.soares@ufv.br

\section{Maria de Lourdes Pinheiro de Azevedo}

Socióloga, mestranda do Programa de Pós-Graduação em Arquitetura e Urbanismo do Departamento de Arquitetura e Urbanismo da Universidade Federal de Viçosa, Universidade Federal de Viçosa, Centro de Ciências Exatas e Tecnológicas, Departamento de Arquitetura e Urbanismo, Campus UFV, CEP 36570-000, Viçosa, MG, maria.l.azevedo@ufv.br

\section{Resumo}

Neste artigo apresenta-se um panorama da instituição de Zonas Especiais de Interesse Social (ZEIS) em cidades médias de Minas Gerais, a partir do estudo exploratório das leis urbanísticas dos municípios de Governador Valadares, Ipatinga, Divinópolis, Sete Lagoas, Ribeirão das Neves e Uberaba. Verificouse que esse instrumento está sendo incorporado na legislação urbanística analisada, contudo, na maior parte dos casos, as ZEIS são estabelecidas apenas em áreas já ocupadas. As barreiras para instituição de ZEIS em áreas vazias limitam o cumprimento da função social da propriedade, indicando que há um longo caminho na efetiva implementação desse instrumento de planejamento urbano.

Palavras-chave: ZEIS, cidades médias de Minas Gerais, instrumentos de planejamento urbano.

\section{Ítalo Itamar Caixeiro Stephan}

Arquiteto, professor adjunto do Departamento de Arquitetura e Urbanismo da Universidade Federal de Viçosa, Universidade Federal de Viçosa, Centro de Ciências Exatas e Tecnológicas, Departamento de Arquitetura e Urbanismo, Campus UFV, CEP 36570-000, Viçosa, MG, stephan@ufv.br

\section{Aline Werneck Barbosa de Carvalho}

Engenheira Arquiteta, professora associada do Departamento de Arquitetura e Urbanismo da Universidade Federal de Viçosa, Universidade Federal de Viçosa, Centro de Ciências Exatas e Tecnológicas, Departamento de Arquitetura e Urbanismo, Campus UFV, CEP 36570-000, Viçosa, MG, abarbosa@ufv.br

\section{Paulo Tadeu Leite Arantes}

Engenheiro Arquiteto, professor associado do Departamento de Arquitetura e Urbanismo da Universidade Federal de Viçosa, Universidade Federal de Viçosa, Centro de Ciências Exatas e Tecnológicas, Departamento de Arquitetura e Urbanismo, Campus UFV, CEP 36570-000, Viçosa, MG, paulotla@gmail.com

presente artigo oferece um panorama da implantação de Zonas Especiais de Interesse Social (ZEIS) em algumas cidades de porte médio de Minas Gerais, a partir de uma investigação acerca da sua instituição na legislação urbanística municipal. O trabalho é resultado da primeira etapa de uma pesquisa de mestrado sobre a implantação de ZEIS em cidades médias de Minas Gerais e sua influência na localização da habitação de interesse social.

A Zona Especial de Interesse Social (ZEIS) é um

1 Essa lei altera a Lei $6.766 / 79$. instrumento urbanístico que começou a ser usado a partir da década de 1980, como resultado das lutas de moradores de assentamentos irregulares por melhoria das condições urbanísticas e regularização fundiária. O objetivo deste instrumento é a inclusão no zoneamento da cidade de uma categoria que permita, mediante um plano específico de urbanização, estabelecer padrões urbanísticos próprios e em geral mais flexíveis para determinados assentamentos. (ROLNIK, 2006).

A discussão acerca desse tema esteve presente nas ações dos movimentos sociais pelo direito à moradia urbana desde meados da década de 1970, culminando na sua inclusão como um dos instrumentos de regularização fundiária na Lei do Parcelamento do Solo Urbano (Lei 9.785 de 29/01/99') e no artigo $4^{\circ}$ da Lei n. 10.257/2001 Estatuto da Cidade (MIRANDA; MORAES, 2007).

A partir de então, esse instrumento vem sendo incorporado nas leis urbanísticas de municípios brasileiros, especialmente naqueles onde a dinâmica 
urbana impõe ações mais efetivas na regulação das áreas destinadas a habitação de interesse social.

Com a finalidade de evidenciar como tem ocorrido a inclusão deste instrumento nas cidades médias de Minas Gerais, apresentou-se, inicialmente, uma breve problematização da questão e sua inserção no contexto das cidades brasileiras; em seguida, discorreu-se sobre o conceito, características e tipos de ZEIS e, finalmente, apresentou-se a análise dos resultados relativos a cada uma das cidades selecionadas como estudos de casos.

\section{O problema}

As cidades brasileiras abrigam grande parte de seus domicílios em situação irregular, em más condições de atendimento de infraestrutura urbana ou em áreas de risco. A situação de vulnerabilidade social em que vivem muitas famílias repete-se em diferentes cidades do país. De acordo com Rolnik (2010, p. 10): "Esta realidade é fruto de políticas de planejamento e gestão urbana excludentes, que não consideram as diferentes demandas sociais e econômicas da população brasileira e são baseadas em padrões de regulação urbanística voltados para setores restritos das cidades".

o padrão de ocupação do espaço urbano nas cidades brasileiras, que se fundamenta na lógica da expansão horizontal, tem acarretado, desde muitos anos, excessivos deslocamentos da população, a ocupação de áreas de preservação ambiental e uma grande quantidade de vazios urbanos em áreas já infraestruturadas, com bom potencial para ocupação, reservadas geralmente para fins de especulação imobiliária. Como resultado, há sempre uma demanda por investimentos públicos de grande porte, cujo atendimento depende não apenas de recursos financeiros, mas, também, dos interesses políticos em jogo.

A necessidade de enfrentamento dos problemas sociais e habitacionais, o questionamento do modelo tradicional de planejamento e desenvolvimento urbano e a pressão dos movimentos populares levaram à criação de instrumentos de controle e gestão do uso do solo urbano. Com a introdução de instrumentos de política urbana nos capítulos 182 e 183 da Constituição Federal de 1988 e, mais tarde, com a sua regulamentação pelo Estatuto da
Cidade (Lei n. 10.257/2001), deu-se maior ênfase aos instrumentos jurídico- urbanísticos destinados a fazer cumprir a função social da cidade, cabendo aos municípios definir aqueles que devem ser aplicados na sua legislação. A partir de então, houve a implementação de forma diversificada de alguns desses instrumentos, dentre eles, a implantação e demarcação de ZEIS.

A ZEIS constitui um instrumento urbanístico que começou a ser usado a partir da década de 1980, como resultado das lutas de moradores de assentamentos irregulares para melhoria das condições urbanísticas e regularização fundiária. O objetivo deste instrumento é a inclusão no zoneamento da cidade de uma categoria que permita, mediante um plano específico de urbanização, estabelecer padrões urbanísticos próprios e em geral mais flexíveis para determinados assentamentos (ROLNIK, 2006; SAULE JÚNIOR, 2006; MIRANDA; MORAES, 2007).

É sabido que em grandes cidades e regiões metropolitanas, a situação habitacional da população mais carente é extremamente precária e que a criação das ZEIS colaborou para a efetivação de políticas de regularização fundiária e implantação de melhorias em infraestrutura de certas localidades, como nas favelas em Recife, Belo Horizonte, Santos, entre outras.

Contudo, os problemas sociais e habitacionais não são exclusivos das grandes cidades. As cidades médias enfrentam problemas semelhantes relacionados à carência de terrenos bem localizados para a produção de habitação de interesse social. Essa categoria de cidades, caracterizadas pelo IBGE (Instituto Brasileiro de Geografia e Estatística) como aquelas que possuem população entre 100 e 500 mil habitantes, comumente não apresentam problemas tão complexos quanto os das grandes cidades e regiões metropolitanas, no entanto, repetiram ao longo da história o modelo tradicional de planejamento urbano e produção da habitação de interesse social em áreas distantes dos centros urbanos.

Nos últimos anos, as cidades médias foram as que mais cresceram em número de habitantes no Brasil? o que justifica a utilização dos instrumentos urbanísticos para controlar e direcionar o uso do solo urbano. O crescimento urbano acelerado 


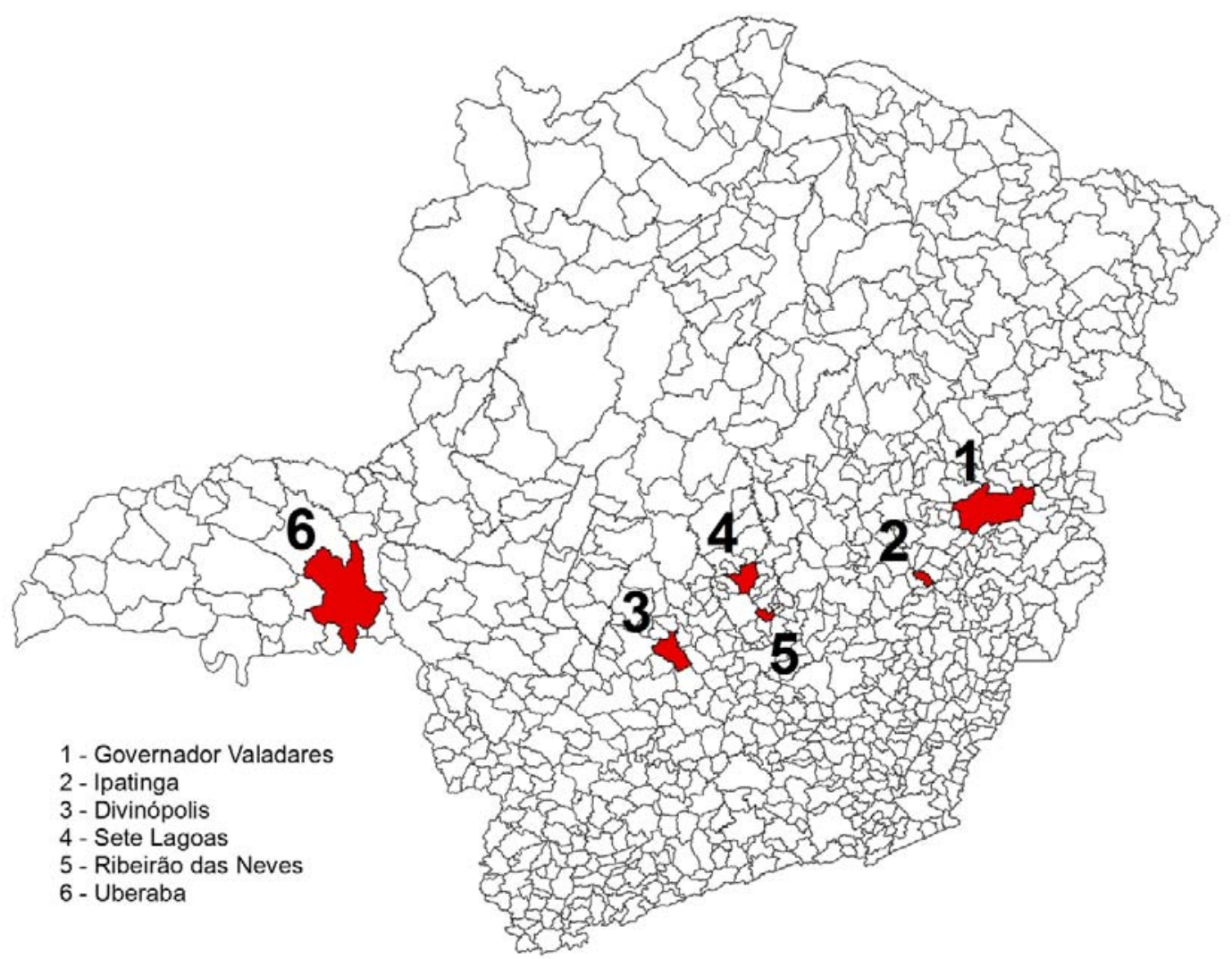

Figura 1: Localização dos municípios pesquisados. Fonte: Isabelle Oliveira Soares e co-autores. tem provocado nestas cidades problemas muito semelhantes aos dos grandes centros urbanos, como as invasões de terrenos públicos e privados, os loteamentos irregulares, a formação de favelas e o precário atendimento de transporte coletivo e infraestrutura urbana nos assentamentos periféricos.

Com a intenção de aprofundar o estudo das questões relacionadas à habitação de interesse social e de como os instrumentos urbanísticos têm sido aplicados para garantir o direito à cidade, depara-se com a carência de estudos relativos às pequenas e médias cidades, cujo estado da arte é ainda pouco expressivo quando comparado ao amplo conjunto de pesquisas direcionadas para as metrópoles.

Diante do exposto, a proposta deste artigo consiste em responder à seguinte pergunta: Como o instrumento ZEIS tem sido aplicado na legislação urbanística das cidades de porte médio de Minas Gerais?
Para responder a esta pergunta, dentre o universo de 25 cidades com população entre 100 e 500 mil habitantes do estado de Minas Gerais, definiuse como recorte espacial seis cidades mineiras com população entre 200 e 300 mil habitantes: Governador Valadares, Ipatinga, Divinópolis, Sete Lagoas, Ribeirão das Neves e Uberaba. A Figura 1 ilustra a localização desses municípios no Estado de Minas Gerais.

A escolha dos estudos de casos justificou-se pela disponibilidade inicial de dados e pela intenção de selecionar municípios que tivessem aproximadamente o mesmo porte populacional.

\section{Objetivos e procedimentos metodológicos}

O objetivo deste trabalho é a produção de um panorama da implantação de ZEIS em algumas cidades de porte médio de Minas Gerais, com população entre 200 e 300 mil habitantes, a partir 
3SANTOS JUNIOR, Orlando Alves dos; MONTANDON, Daniel Todtmann. (org.) Os planos diretores municipais pós estatuto da cidade: balanço crítica e perspectivas. Rio de Janeiro: Letra Capital: Observatório das Cidades: IPPUR/UFRJ, 2011. de um estudo exploratório das leis municipais urbanísticas vigentes.

Para alcançar este objetivo, realizou-se de um estudo exploratório das leis municipais, com a finalidade de identificar se a ZEIS foi incluída entre os instrumentos urbanísticos, quais os tipos de ZEIS instituídas e se essas foram demarcadas no espaço urbano.

Inicialmente, por meio da revisão de literatura, procurou-se identificar o conceito, as características e os diferentes tipos de ZEIS existentes. Além disso, apresentou-se um breve histórico da implantação de ZEIS no Brasil.

Em seguida, realizou-se uma pesquisa exploratória das leis municipais das cidades selecionadas como estudos de casos, incluindo a análise dos planos diretores e de leis específicas relacionadas à criação de ZEIS, como as leis de uso e ocupação do solo urbano. Essa pesquisa documental foi realizada através de "sites" oficiais das Câmaras Municipais, artigos e livros publicados sobre o assunto. Entre a bibliografia consultada, destacase a pesquisa realizada pelo Observatório das Metrópoles, publicada em seu "site" em 2010 e em livro em $2011^{3}$, em que foram analisados os Planos Diretores de inúmeras cidades brasileiras. Das seis cidades apresentadas neste artigo, apenas Uberaba não teve o Plano Diretor avaliado pelo estudo citado.

Após o levantamento documental, procedeu-se ao levantamento de dados sobre os municípios selecionados, visando à sua caracterização geral.

A partir da análise, os dados obtidos a respeito da instituição de ZEIS e de suas características (diferenciação de tipos) foram organizados em um quadro síntese, que proporcionou uma visão geral do resultado da pesquisa.

\section{Revisão de literatura}

De maneira geral, a ZEIS pode ser conceituada como um instrumento de regulação e controle do uso e ocupação do solo, a partir da previsão de parâmetros urbanísticos específicos para as áreas destinadas a habitação de interesse social.

No dizer de Miranda e Moraes (2007, p. 417),
A Zeis se constitui, a princípio, num instrumento de regulação e controle do uso e ocupação do solo, a partir da previsão de parâmetros urbanísticos, dimensões máximas das áreas dos lotes para novos parcelamentos ou resultantes de remembramentos, inibindo, assim, os interesses dos empreendedores imobiliários e comerciais.

Trata-se de um instrumento de ordenação da produção do espaço urbano habitacional, público e privado, visando atender as necessidades dos cidadãos quanto à qualidade de vida, à justiça social e ao desenvolvimento das atividades produtivas (SPINOLA, 2010).

Do ponto de vista jurídico,

as ZEIS são uma espécie de zoneamento dentro do qual se admite a aplicação de regras especiais de uso e de ocupação do solo em áreas já ocupadas ou que venham a ser ocupadas por população de baixa renda, tendo em vista precipuamente a salvaguarda do direito à moradia previsto no artigo $6^{\circ}$ da Constituição da República Federativa do Brasil. (DIAS, 2008, p. 143).

Portanto, a ZEIS tem como objetivo incluir no zoneamento da cidade áreas com padrões específicos de urbanização, com exigências mais brandas para áreas ocupadas irregularmente para fins de moradia, a fim de facilitar o processo de regularização jurídica das mesmas (ALFONSIN, 2002). Essas exigências devem ser estabelecidas para cada caso específico, tendo em vista que cada ocupação pode ter características particulares não compartilhadas com outras áreas.

O procedimento inédito das ZEIS é a elaboração de planos urbanísticos baseados em normas de uso e ocupação do solo adequadas à escala local, para grupos em desvantagem econômica (SPINOLA, 2010). Conforme ensina o jurista Saule Júnior (2006), "a área gravada como ZEIS se torna uma espécie de zona específica e especial, liberada de regras usuais de uso e ocupação do solo e detentora, portanto, de regras especiais". Sendo assim, a ZEIS constitui um instrumento flexível, que aceita a heterogeneidade da cidade, contrariando o padrão homogêneo de urbanização vigente por muito tempo. Esse padrão ignorava o dinamismo do crescimento das áreas periféricas ocupadas pela população de menor poder aquisitivo. 
A instituição das ZEIS traz para o poder público a oportunidade de inclusão social da população mais carente nos núcleos urbanos. De acordo com Rolnik (2006), o instrumento tem como finalidade incluir a população urbana que foi marginalizada pela falta de condições de ocupar o solo conforme a legislação urbanística. Além disso, com a instituição de ZEIS, a administração municipal pode investir na melhoria da infraestrutura urbana das áreas em que essa população está abrigada, o que antes não acontecia em razão desses investimentos serem sempre direcionados para as áreas regularizadas ocupadas por população de maior poder aquisitivo.

Com a regularização de ocupações urbanas e o investimento em infraestrutura, os moradores de ZEIS passam a pagar impostos e taxas, aumentando a arrecadação do município. Nesse sentido, essa regularização torna-se interessante ao poder público, uma vez que a sua receita passa a ser maior e a população passa a ter uma melhor qualidade de vida. (ROLNIK, 2006)

As ZEIS também têm potencial para controlar a especulação imobiliária sobre os terrenos das áreas demarcadas, já que com a demarcação dessas zonas, há uma maior oferta de terras para os mercados urbanos, o que pode reduzir o preço da terra, equiparando-o aos dos terrenos mais distantes, onde em geral habita a população carente. Assim, há a possibilidade dessa população ser inserida na cidade de uma forma mais justa.

Segundo Saule Júnior (2006), as ZEIS podem ser classificadas em duas tipologias: a ZEIS de áreas ocupadas e a ZEIS de áreas vazias. A primeira serve à regularização fundiária de áreas já ocupadas, como favelas, loteamentos irregulares e/ou clandestinos, edificações deterioradas ocupadas pela população de baixa renda (cortiços), ocupações irregulares em áreas remanescentes de quilombos ou em áreas de valor ambiental, entre outros. A maior parte das experiências na demarcação de ZEIS é desse tipo. Contudo, as ZEIS também podem ser demarcadas em áreas vazias na cidade, nos vazios urbanos, que em geral são destinados à especulação imobiliária. Essa demarcação possibilitaria novos empreendimentos destinados à população carente, que já nasceriam regularizados e inseridos no contexto das cidades. Entretanto, a demarcação desse tipo de ZEIS em locais desocupados é mais difícil porque esse tipo de proposta gera conflitos com os proprietários dos imóveis inseridos nesses locais. Com a aplicação desse instrumento, tais proprietários passam a ter menos possibilidades de aproveitamento do solo urbano. Trata-se de uma restrição de uso que afeta diretamente o valor do imóvel. (ROLNIK; CYMBALISTA; NAKANO, 2002, p.22)

A história da utilização desse instrumento no Brasil demonstra essa situação, pois a maioria das aplicações do instrumento ocorreu em áreas já ocupadas, tendo como principal objetivo a sua regularização.

O ponto de partida dessa história foi a experiência do Pró-Favela, em Belo Horizonte-MG, do começo da década de 1980, quando a lei de zoneamento de 1976 foi alterada, incluindo a classificação "Setor Especial 4" para as favelas, o que representou uma formulação inovadora. Segundo Fernandes (2003, p. 144):

A lei que criou o Pró-Favela de Belo Horizonte, de 1983, foi pioneira no país, ao propor um programa urbanístico e social de regularização das favelas, tendo introduzido uma fórmula original: a combinação entre a identificação e a demarcação de favelas com áreas residenciais para fins de moradia social - inicialmente denominadas "Setores Especiais" - no contexto do zoneamento municipal; a definição de normas urbanísticas especiais de uso, de parcelamento e de ocupação do solo em tais áreas; e a criação de mecanismos político-institucionais de gestão participativa dos programas de regularização. Essa fórmula tornou-se um paradigma seguido por diversas outras cidades, como Recife, Salvador e Porto Alegre (...).

Pouco depois, em Recife-PE, na lei de uso e ocupação do solo, datada de 1983, foram delimitadas áreas para a criação da Zona Especial de Interesse Social para assentamentos habitacionais surgidos espontaneamente. Para essas áreas foram constituídas normas urbanísticas especiais, com o intuito de promover a regularização jurídica e a relação dos novos bairros com a estrutura urbana existente. Contudo, a aplicação das ZEIS ocorreu somente em 1987 quando foi regulamentada pela lei do Plano de Regularização das ZEIS - PREZEIS. Este plano contou, na sua elaboração, com ampla participação social 
e teve como liderança a presença forte de líderes religiosos (ANCONA, 2011, p.4).

Abordando estas duas experiências, Miranda e Moraes (2007) argumentam que o Pró-Favela não avançou significativamente, no âmbito institucional, em relação aos processos participativos de planejamento e gestão, ficando distante da estrutura complexa de gestão do Prezeis.

Entretanto, as experiências de Belo Horizonte, com o Projeto Pró-Favela e, mais especialmente, a de Recife, com o PREZEIS, tornaram-se referência para as demais cidades brasileiras na constituição das suas zonas especiais para fins de moradia (SPINOLA, 2010; SANTOS, 2010; CALDAS, 2009).

As experiências apresentadas até então, apesar de terem se constituído em um grande avanço no que diz respeito à regularização fundiária, ainda não tinham incluído as áreas não ocupadas. A demarcação de ZEIS em áreas vazias foi realizada pela primeira vez na cidade de Diadema, na região metropolitana de São Paulo.

A administração democrática e popular dessa cidade, no período de 1983 a 1996, abriu canais de participação para que os movimentos populares pudessem influir na política desenvolvida pelo governo. O resultado bem sucedido dessa participação foi o atendimento dos segmentos sociais de baixa renda com áreas para moradia. O governo municipal de Diadema, de forma pioneira, criou e implementou esse tipo de ZEIS antes mesmo da aprovação do Estatuto da Cidade, numa ocasião em que, no país, os movimentos sociais bem organizados lutavam pela reforma urbana. De acordo com ANCONA (2011), o município tinha uma liderança comprometida com as questões socioterritoriais. Neste contexto, em 1994, o Plano Diretor

aprovou a delimitação de terrenos particulares, não edificados, como área de Especial de Interesse Social-AEIS, do tipo 1, e definiu tais perímetros como terrenos não edificados, sub-utilizados ou não utilizados, necessários à implantação de empreendimentos habitacionais de interesse social (ANCONA, p.5 2011).

A experiência de Diadema transformou-se num exemplo, onde o instrumento ZEIS foi desenhado para a regularização fundiária, além de demarcar áreas particulares para a implantação de projetos de habitação de interesse social, o que de fato se efetivou. Após cinco anos da aprovação das ZEIS na legislação municipal, $80 \%$ dos terrenos demarcados já haviam sido usados para esse fim. (BALTRUSIS, 2003).

Após o sucesso na implantação de ZEIS em algumas cidades, o governo federal alterou a Lei n. 6.766/79, (através da Lei n. 9.785/99) introduzindo novos padrões de infraestrutura básica para a aprovação de loteamentos urbanos. A Lei n. 9.785/99 definiu uma redução de tais exigências para o caso de "parcelamentos situados em zonas habitacionais declaradas por lei como de interesse social - ZHIS" (artigo $\left.2^{\circ}, \S 6^{\circ}\right)$.(ANCONA, 2011; MIRANDA; MORAES, 2007).

Em 2001, o Estatuto da Cidade foi aprovado, contendo a ZEIS entre os demais instrumentos urbanísticos. A partir de então, estas "se tornaram o principal instrumento de política habitacional contemplado pelos Planos Diretores" (ANCONA, 2011, p.5)

Contudo, a aplicação desse instrumento aconteceu principalmente em grandes cidades e regiões metropolitanas, embora as cidades de porte médio já estejam incorporando este instrumento na sua legislação urbanística.

Visando um aprofundamento nessas questões, passou-se a analisar como algumas cidades de porte médio de Minas Gerais têm estabelecido esse instrumento em sua legislação.

\section{Resultados e discussões}

O conceito de cidades médias não é consensual. Vários autores apontam que o critério populacional é insuficiente para classificar as cidades quanto ao porte, acrescentando outros fatores que contribuiriam para a esta delimitação, como, por exemplo, sua importância funcional na rede urbana.

Na tentativa de identificar as cidades médias de Minas Gerais e dando continuidade a um estudo sobre o conceito de cidade médias realizado na década de 1980, Amorim Filho, Bueno e Abreu (1982, apud AMORIM FILHO; RIGOTTI, 2002) observaram e 
${ }^{4}$ As ACPs foram definidas como grandes manchas urbanas de ocupação contínua, caracterizadas pelo tamanho e densidade da população, pelo grau de urbanização e pela coesão interna da área, dada pelos deslocamentos da população para trabalho ou estudo.

5 A demanda habitacional demográfica não se confunde com o déficit habitacional, embora considere fatores que costumam ser computados no déficit. "Refere-se à formação de um novo arranjo domiciliar (familiar ou nãofamiliar), em consequência da dinâmica demográfica e social"(CAIXA, 2011, p. 30). São incluídos como demandantes de novas moradias os adultos com idade de 24 a 64 anos, que têm condições de formar um novo arranjo habitacional. identificaram quatro níveis hierárquicos: grandes centros regionais - nível limiar que marca a faixa de transição para o grupo das grandes cidades; cidades médias de nível superior - formado por cidades médias bem consolidadas; cidades médias propriamente ditas - grupo de que fazem parte cidades que apresentam os atributos teoricamente característicos das cidades médias mais típicas; centros urbanos emergentes - onde se encontra um número bastante considerável de cidades pertencentes à faixa de transição entre as pequenas e as médias cidades.

Em 2005, Amorim Filho deu continuidade aos estudos anteriores, classificando as cidades quanto ao porte por meio de indicadores como: demografia, atividades econômicas (agropecuárias e extrativas, industriais, comerciais e de serviços), e comunicações e transportes (AMORIM FILHO; RIGOTTI; CAMPOS, 2007). De acordo com esses estudos, as cidades de Uberaba, Governador Valadares, Sete Lagoas, Divinópolis e Ipatinga foram classificadas como cidades médias de nível superior. A cidade de Ribeirão das Neves não apareceu nesta classificação, mas faz parte da Região Metropolitana de Belo Horizonte.

Outro estudo que apresenta uma classificação para as cidades brasileiras é o trabalho realizado pelo IBGE denominado "Regiões de Influência das Cidades 2007" (IBGE, 2008). Nesse trabalho não foi adotada uma classificação das cidades utilizando-se o termo cidades médias. Inicialmente foi estabelecida uma classificação dos centros em diferentes níveis, na qual "privilegiou-se a função de gestão do território, avaliando níveis de centralidade do Poder Executivo e do Judiciário no nível federal, e de centralidade empresarial, bem como a presença de diferentes equipamentos e serviços" (IBGE, 2008, p.11). Na segunda etapa do trabalho foram delimitadas áreas de atuação dos centros identificados, mediante o levantamento das ligações entre as cidades, o que permitiu delinear suas áreas de influência e esclarecer a articulação das redes no território (IBGE, 2008, p.11). Para as cidades que constituem grandes aglomerações urbanas, a unidade de observação foi o conjunto da Área de Concentração de População - ACP 4 . No caso de Minas Gerais, as ACPs definidas foram Belo Horizonte, Ipatinga-Coronel FabricianoTimóteo, Juiz de Fora e Uberlândia. Na hierarquia dos centros urbanos, as cidades foram classificadas em cinco grandes níveis, subdivididos em dois ou três sub-níveis: metrópoles (grande metrópole nacional, metrópole nacional e metrópole); capital regional, com três sub-níveis ( $A, B$ ou $C$ ); centro sub-regional, com três sub-níveis ( $A, B$ ou $C$ ); centro de zona, com dois sub-níveis (A ou B) e centro local. De acordo com este estudo, as cidades de Uberaba, Divinópolis e Governador Valadares foram classificadas como "capital regional C", isto é centros que, como as metrópoles, também se relacionam com o estrato superior da rede urbana, mas possuem capacidade de gestão no nível imediatamente inferior ao das metrópoles. Essas capitais têm área de influência de âmbito regional, sendo referidas como destino para um grande número de atividades por muitos municípios (IBGE, 2008).

Em termos de carência por habitação, tem-se que as cidades de Governador Valadares, Ipatinga, Divinópolis, Sete Lagoas, Ribeirão das Neves e Uberaba apresentam uma demanda habitacional demográfica ${ }^{5}$ da ordem de $11 \%$ a 15\% do número de domicílios, o que as situa na mesma faixa encontrada para o Estado de Minas Gerais (12,6\%) e para o Brasil (11,9\%). (CAIXA ..., 2011).

Após situar as cidades selecionadas como estudos de caso na rede urbana mineira e apresentar, em linhas gerais, sua demanda por habitação de interesse social, apresentam-se os resultados da análise da instituição de ZEIS na legislação urbanística de cada município.

\section{Governador Valadares}

O município de Governador Valadares (Figura 2) está localizado na Mesorregião do Vale do Rio Doce e tem área de 2.342,316 Km². De acordo com o Censo Demográfico realizado pelo IBGE(2010), a população residente é de 263.689 habitantes, sendo a densidade demográfica de 112,58 hab/Km .

A Lei Complementar n. 031, de 27 de abril de 2001, que dispõe sobre o Programa Municipal de Regularização Urbanística e Fundiária de Governador Valadares define como Zonas Habitacionais de Interesse Social - ZHIS as áreas não regularizadas ocupadas por populações de baixa renda, carentes de infraestrutura, nas quais haja interesse público em promover a urbanização fundiária. Contudo, essas áreas não foram delimitadas nessa lei, tendo ficado a cargo do executivo municipal a delimitação das áreas caracterizadas como ZHIS. 


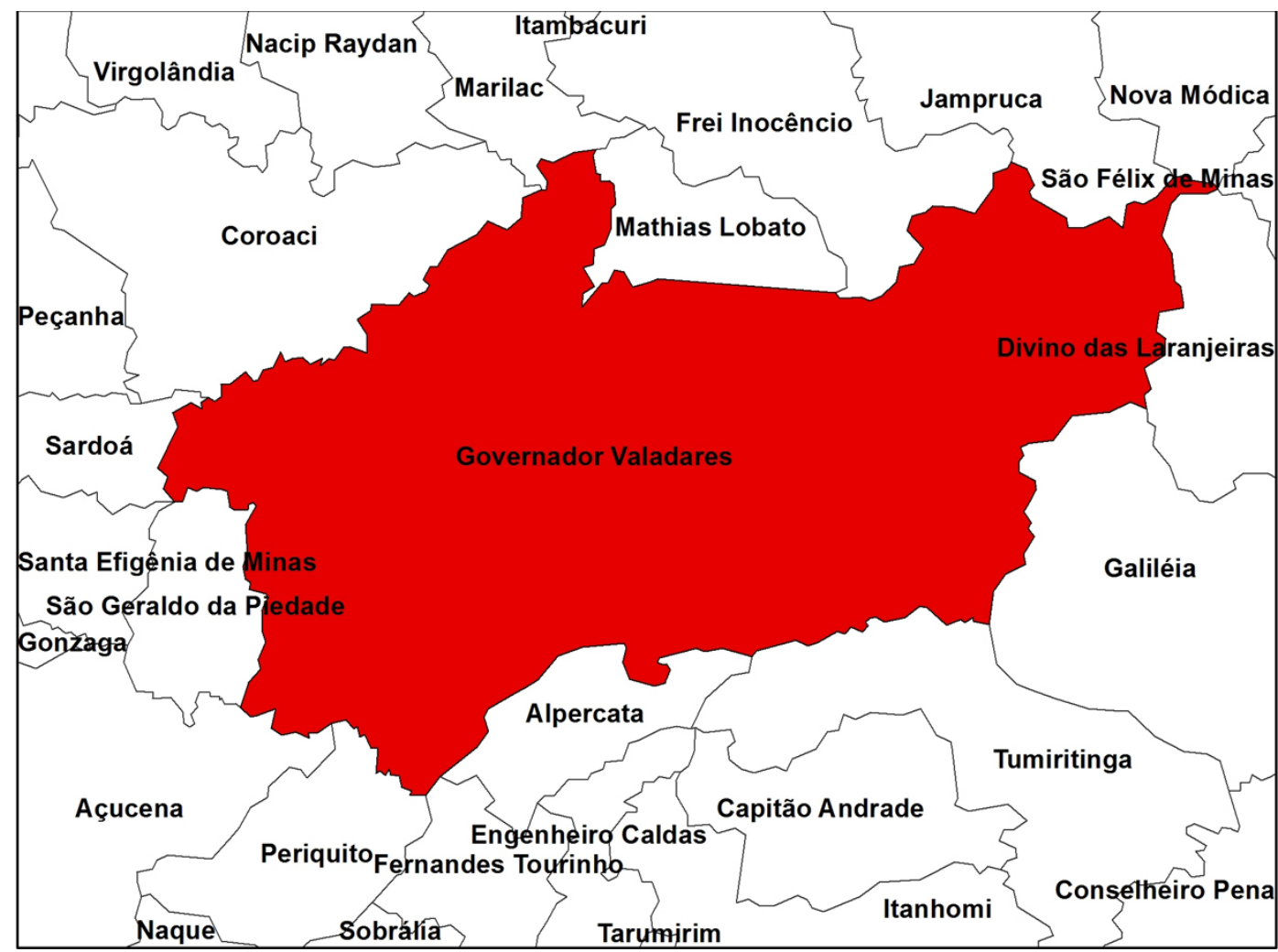

Figura 2: Município de Governador Valadares e Municípios Limítrofes. Fonte: Isabelle Oliveira Soares e co-autores.
O Plano Diretor de Desenvolvimento do Município de Governador Valadares (Lei n. 95, de 27 de dezembro de 2006) retoma o tema da regularização urbanística e fundiária tratando as ZHIS como áreas prioritárias para a regularização. Ao mesmo tempo, estabelece que para a aplicação do instrumento seja elaborado um plano de intervenção contendo, no mínimo: delimitação da área a ser atingida; diagnóstico urbanístico, social e ambiental; projetos de urbanização; programa de mobilização social e educação ambiental da comunidade diretamente afetada pela operação e legislação de uso e ocupação do solo para o assentamento regularizado.

Contudo, ao se analisar as leis municipais que alteraram a Lei de Zoneamento da cidade, de 2001 até hoje não houve nenhuma inclusão ou demarcação de ZHIS. Sendo assim, apesar da definição em lei, o instrumento não saiu da legislação para a prática, o que compromete qualquer intenção de regularização de assentamentos na cidade. Ressalta-se que áreas vazias para a produção de habitação de interesse social não foram ao menos mencionadas na legislação.

\section{Ipatinga}

O município de Ipatinga (Figura 3), componente da região Metropolitana do Vale do Aço, de acordo com o Censo Demográfico realizado pelo IBGE (2010) possui população de 239.468 habitantes. A área do município é de $164,884 \mathrm{Km}^{2}$ e a densidade demográfica de 1.452,34 hab/Km², considerada alta para uma cidade de porte médio. O município, assim como Governador Valadares, está localizado na Mesorregião do Vale do Rio Doce.

O Plano Diretor de Ipatinga (Lei n. 2230/2006) define como ZEIS:

I - áreas de intervenção urbana, sob os aspectos jurídicos, urbanísticos, territoriais, culturais, econômicos e sócio-ambientais, visando a legalizar a permanência de populações nas áreas urbanas 


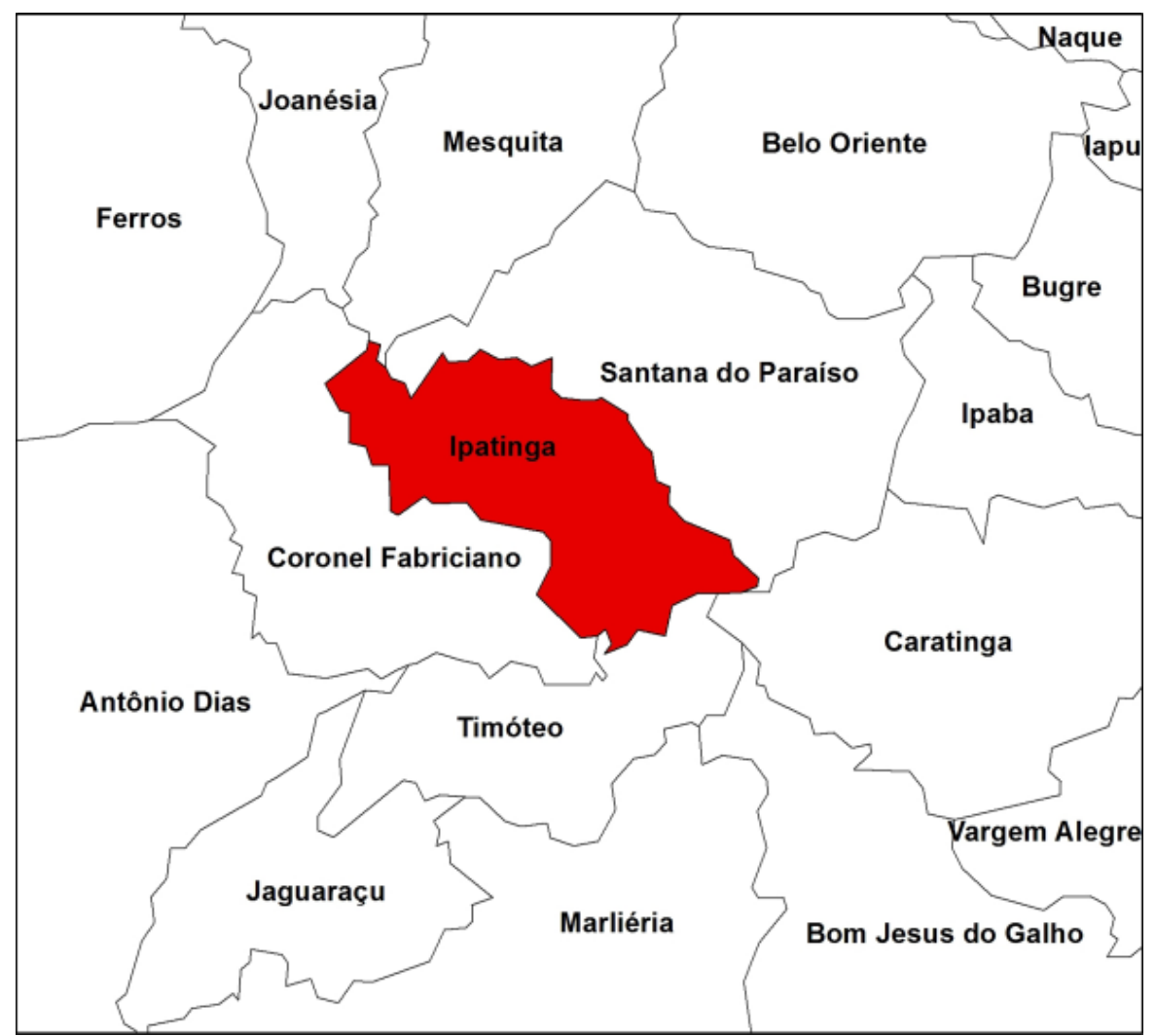

Figura 3: Município de Ipatinga e Municípios Limítrofes. Fonte: Isabelle Oliveira Soares e co-autores. ocupadas em desconformidade com a lei e objetivando melhorias no ambiente urbano do assentamento, por meio da execução do plano de urbanização, no resgate da cidadania e da qualidade de vida da população beneficiária;

II - áreas irregulares ocupadas por população de média e alta renda que poderão ser objeto de regularização jurídica, mediante contrapartida financeira em favor da cidade, de acordo com a regulação a ser estabelecida em legislação específica. (artigo 72)

O artigo 73 classifica as ZEIS em quatro categorias: ZEIS 1 (áreas de conjuntos habitacionais populares); ZEIS 2 (áreas regularizadas através de Concessão de Direito Real de Uso); ZEIS 3 (áreas ribeirinhas ou localizadas sob a rede de alta tensão) e ZEIS 4 (áreas públicas ou privadas ocupadas desordenadamente e não regularizadas).

No texto dessa lei, não há diferenciação entre ZEIS destinadas à regularização fundiária e ZEIS de áreas vazias, mas há a indicação de que deve ser priorizada a construção de habitação popular nos vazios existentes dentro das zonas demarcadas. Todavia, não é possível identificar no mapa da malha urbana quais áreas já foram ocupadas e quais ainda possuem terrenos vagos, disponíveis para novos parcelamentos. Também não foram instituídos parâmetros de uso e ocupação do solo para nenhum dos zoneamentos propostos. Sendo assim, não há regras específicas e mais brandas para ocupação de ZEIS, o que traz a exigência de uma lei específica para tratar da regularização fundiária. Além disso, não foi possível, através do Plano Diretor, entender qual a intenção do poder público em relação às ZEIS 3 , tendo em vista que essas áreas não são passíveis de regularização.

Nesse Plano, define-se como habitação de interesse social aquela "destinada à população que vive em condições precárias de habitabilidade ou de menor renda familiar" (Artigo 96). Porém, também são definidas como ZEIS as áreas irregulares ocupadas por população de média e alta renda, o que parece 
Figura 4: Município de Divinópolis e Municípios Limítrofes. Fonte: Isabelle Oliveira Soares e co-autores. contraditório, mesmo que essa regularização seja realizada mediante contrapartida financeira em favor da cidade.

Por fim, o Plano Diretor deixa a cargo do Poder Executivo a elaboração do projeto de lei que estabeleça o zoneamento e as condições de uso e ocupação do solo urbano, abrangendo a Zona de Especial Interesse Social e de outras zonas, tendo fixado o prazo de um ano para o encaminhamento do projeto de lei à Câmara Municipal. Porém, até o momento da pesquisa, acredita-se que a lei não foi aprovada, pois não foi encontrada no "site" da Câmara Municipal de Ipatinga, onde todas as leis municipais são disponibilizadas.

\section{Divinópolis}

De acordo com Censo Demográfico de 2010 realizado pelo IBGE, Divinópolis tem uma população de 213.016 habitantes, área de $708,115 \mathrm{Km}^{2}$ e densidade demográfica de $300,82 \mathrm{hab} / \mathrm{Km}^{2}$. O município está localizado na Mesorregião Oeste de Minas (Figura 4).
Desde 1988, mesmo ano de aprovação da Constituição Federal, foi aprovada a Lei de Uso e Ocupação do Solo do município de Divinópolis (Lei n. 2.418/1988), que inclui um macrozoneamento do seu território. Esse macrozoneamento divide o município em sete zonas: Zona Residencial (ZR), Zona Comercial (ZC), Zona de Usos Múltiplos (ZUM), Zona Industrial (ZI), Zona Especial (ZE), Zona de Expansão Urbana e Zona Rural.

As Zonas Especiais são ainda subdivididas em quatro tipos: ZE-1, ZE-2, ZE-3 e ZE-4. A Zona Especial 1 "compreende os espaços destinados ao desenvolvimento de projetos especiais, tais como: ampliação do sistema viário e áreas destinadas ao Programa Municipal de Habitação, todos de iniciativa do poder público" ( $\S 1^{\circ}$, Artigo 13, Lei n. 2.418/88). A Lei indica que o poder executivo municipal é o responsável por regulamentar a ocupação dessas zonas ou descaracterizálas para áreas privadas, atribuindo a elas um novo zoneamento. Para as áreas públicas essa descaracterização dependeria da aprovação de uma lei municipal.

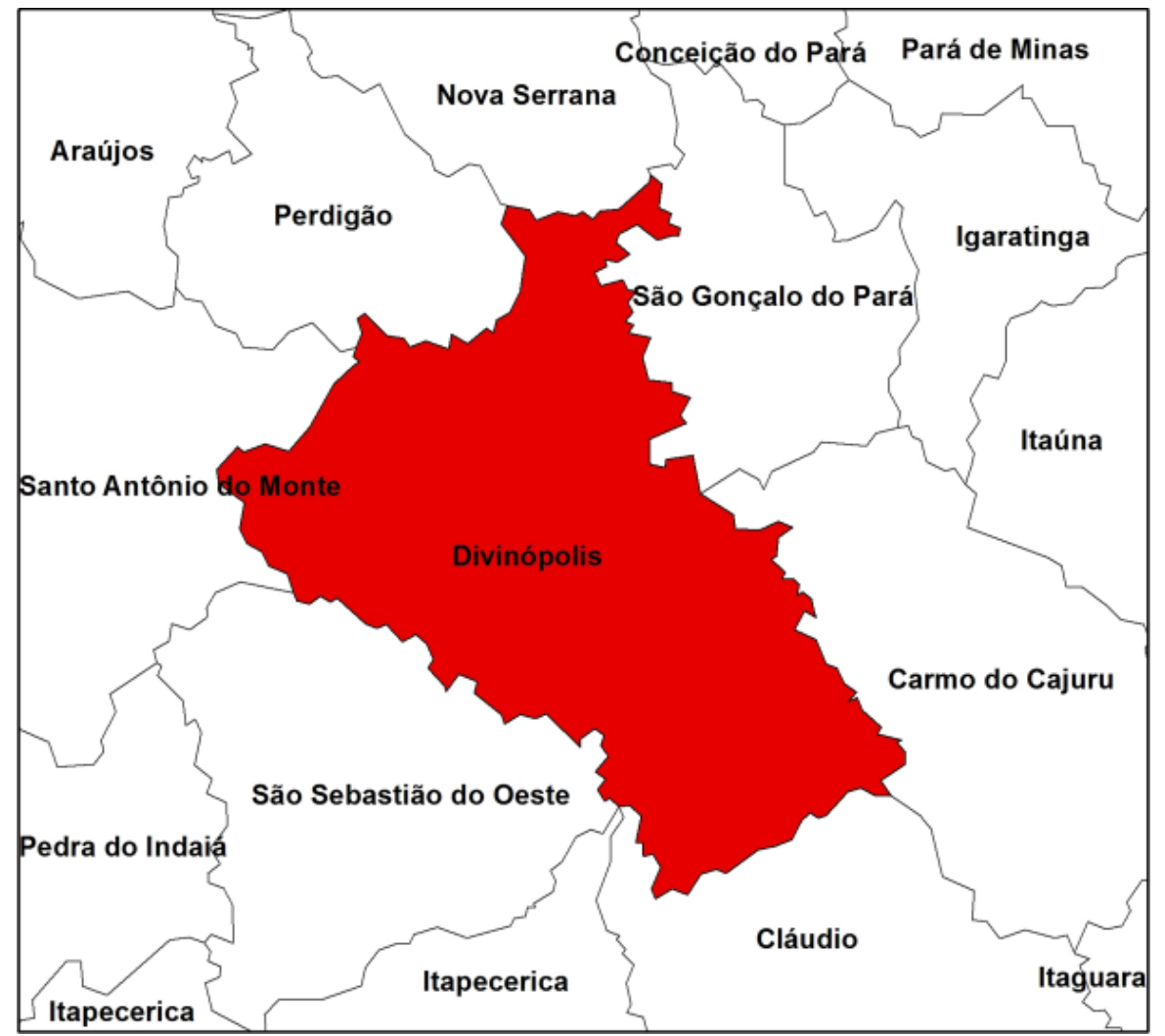


Figura 5: Município de Sete Lagoas e Municípios Limítrofes. Fonte: Isabelle Oliveira Soares e co-autores.
A ZE-1, por delimitar áreas vazias para diversos projetos "especiais" do poder público, poderia ser utilizada como uma ZEIS de áreas vazias para a implantação de habitação de interesse social. Contudo, acredita-se que a falta de demarcação de áreas específicas para a construção de moradias pode impedir a utilização efetiva das ZE-1 para esse fim. Além disso, a possibilidade de descaracterização dessas áreas não garante a formação de um "banco de terras" destinado à produção de habitação social, nem mesmo um estímulo à produção privada de moradias para a população de menor renda.

A ZE-4 "compreende os espaços com ocupação irregular do ponto de vista jurídico e urbanístico caracterizados por habitações subnormais e população economicamente carente" ( $\S 4^{\circ}$, Artigo 13, Lei n. 2.418/88). A Lei indica que neste caso podem ser descaracterizadas as áreas em que o proprietário tem plena posse e domínio de seu imóvel.

Essa zona pode ser comparada a uma ZEIS de regularização fundiária, pois as áreas caracterizadas acima são como aquelas geralmente atendidas por esse instrumento. Além disso, a Lei n. 2.418/1988 dá ao poder público a possibilidade de admitir limitações urbanísticas menos restritivas para programas e projetos de interesse social destinados à população de baixa renda, o que é a premissa básica de ZEIS desse tipo.

O Plano Diretor de Divinópolis, Lei Municipal $n$. 060/2000, menciona que é de responsabilidade do poder executivo municipal a regulamentação e descaracterização das áreas situadas em ZE-1 e ZE-4. Além disso, estabelece que novas Zonas Especiais serão definidas, a critério do Órgão Municipal de Planejamento, com o objetivo de assegurar áreas livres para implantação de projetos de desenvolvimento urbano, incluindo programas de habitação de interesse social, e que neste caso as áreas devem ser contíguas à malha urbana. Entretanto, como essas áreas não ficam demarcadas e instituídas no plano diretor, não há a garantia de que terrenos bem localizados na cidade serão destinados à produção de moradias para a população carente.

\section{Sete Lagoas}

O município de Sete Lagoas (Figura 5) está situado na Região Metropolitana de Belo Horizonte. Possui área

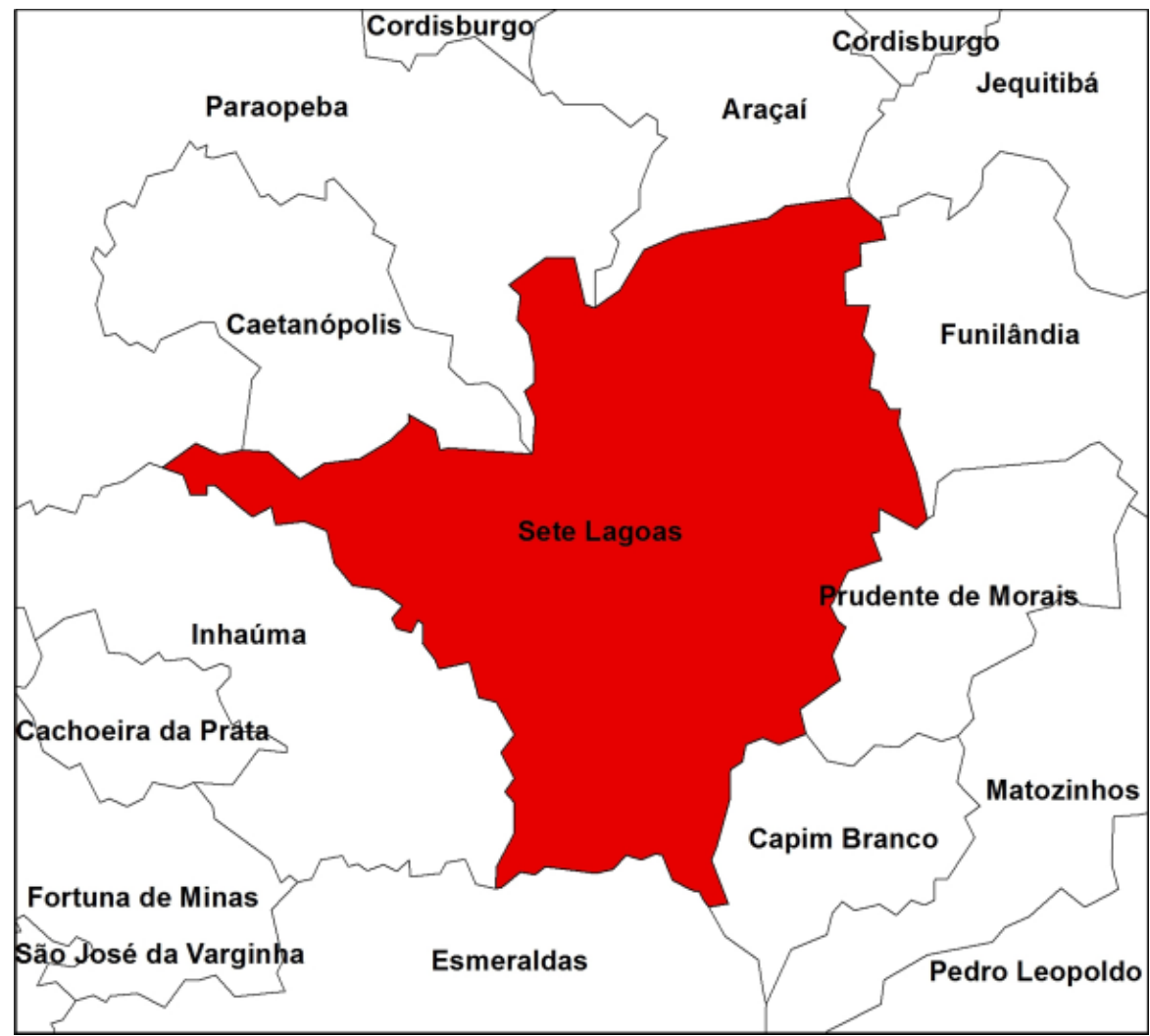


Figura 6: Município de Ribeirão das Neves e Municípios Limítrofes. Fonte: Isabelle Oliveira Soares e co-autores. de 537,638 Km² e densidade demográfica de 398,32 hab/Km². De acordo com o Censo Demográfico realizado pelo IBGE em 2010, a população residente é de 214.152 habitantes.

O Plano Diretor de Sete Lagoas, Lei municipal n. 109/2006, estabelece a subdivisão da Zona Urbana em outras doze zonas, entre essas a Zona de Especial Interesse Social (ZEIS). Nesta lei fica definido que ZEIS são "áreas em que há interesse público em ordenar a ocupação, por meio de urbanização e regularização fundiária ou implantar empreendimentos habitacionais de interesse social" (§ $3^{\circ}$, Artigo 68). Nesta definição não há uma diferenciação entre zonas de áreas vazias e zonas já ocupadas destinadas à regularização fundiária.

O Plano apresenta no Anexo II o mapa com o Zoneamento da área urbana. Porém, no texto não há a especificação das coordenadas que limitam o perímetro dessas zonas. Além disso, o plano não define um prazo para que a demarcação de áreas destinadas à produção da habitação de interesse social seja realizada, nem mesmo que essas áreas devam ser contíguas à malha urbana já existente. Por outro lado, nesse plano são mencionados outros instrumentos que podem ser usados prioritariamente nas ZEIS, entre esses, o Direito de Preempção.

\section{Ribeirão das Neves}

Ribeirão das Neves (Figura 6), também localizado na Região Metropolitana de Belo Horizonte, tem uma população de 296.317 habitantes, de acordo com o Censo Demográfico realizado pelo IBGE em 2010. A área do município é de $154,501 \mathrm{Km}^{2}$ e sua densidade demográfica de 1.917,90 hab/ Km², considerada uma alta densidade, característica das regiões metropolitanas.

Na sua Lei de Uso e Ocupação do Solo (Lei n. 037/2006), foram estabelecidas nove zonas diferentes, sendo que muitas dessas apresentam subdivisões. Esta lei define que

A Zona de Especial Interesse Social - ZEIS compreende áreas de ocupação irregular como áreas de propriedade pública e/ou privada que sofreram invasões, invasões

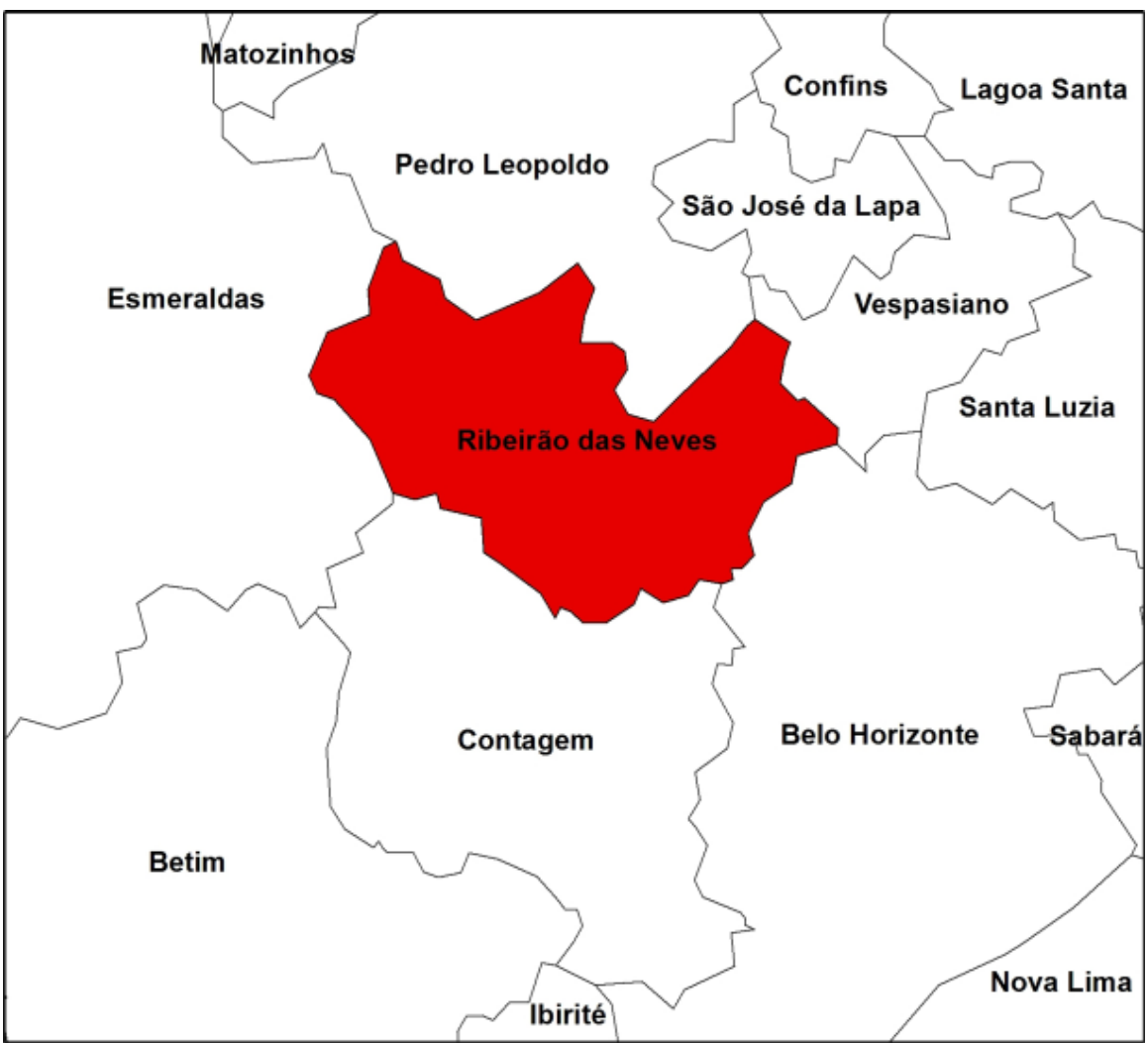


Figura 7: Município de Uberaba e Municípios Limítrofes. Fonte: Isabelle Oliveira Soares e co-autores. em áreas de risco de desabamentos e inundações, invasões em áreas de preservação permanente, entre outras ocupações irregulares similares, que deverão ser objeto de projeto de cadastramento, urbanização e regularização fundiária, projetos de remanejamento integrados a programas habitacionais, no prazo de 12 (doze) meses a contar da data de aprovação desta Lei. (Artigo 12)

Essas ZEIS podem ser entendidas como ZEIS de regularização fundiária. Mas a legislação traz também a Zona de Expansão Urbana de Interesse Social. Essa zona compreende "áreas destinadas à implantação de loteamentos de interesse social e deverão atender às exigências constantes da Lei de Parcelamento do Solo" (Artigo 17, letra g, Lei n. 037/2006). Talvez pela característica peculiar da cidade de Ribeirão das Neves (com grande parte da população de baixa renda e muitos problemas sociais concentrados devido à presença de presídios), há na legislação áreas demarcadas destinadas à regularização de loteamentos irregulares e a equipamentos de uso coletivo voltados para a educação, atividades sociais, culturais, entre outras.
Dessa forma, é possível perceber que apenas a delimitação de ZEIS não seria suficiente para contemplar os diversos problemas relacionados à ocupação desordenada do solo urbano.

Comparando a legislação desse município com a dos demais, percebe-se certo avanço, pois as áreas estão delimitadas em mapas e com usos muito bem definidos. Além disso, há dois tipos de ZEIS demarcadas: as ZEIS de áreas ocupadas para regularização fundiária (definidas na Lei apenas como ZEIS) e as ZEIS de áreas vazias, destinadas à produção de habitação de interesse social (definidas na Lei como ZEU social).

\section{Uberaba}

O Município de Uberaba (Figura 7) está localizado na Mesorregião do Triângulo Mineiro e Alto Paranaíba e tem área igual a 4.523,957 $\mathrm{Km}^{2}$. De acordo com o Censo Demográfico do IBGE(2010), a população residente é de 295.988 habitantes, sendo a densidade demográfica de 65,43 hab/ $/ \mathrm{Km}^{2}$, a mais baixa entre as cidades investigadas.

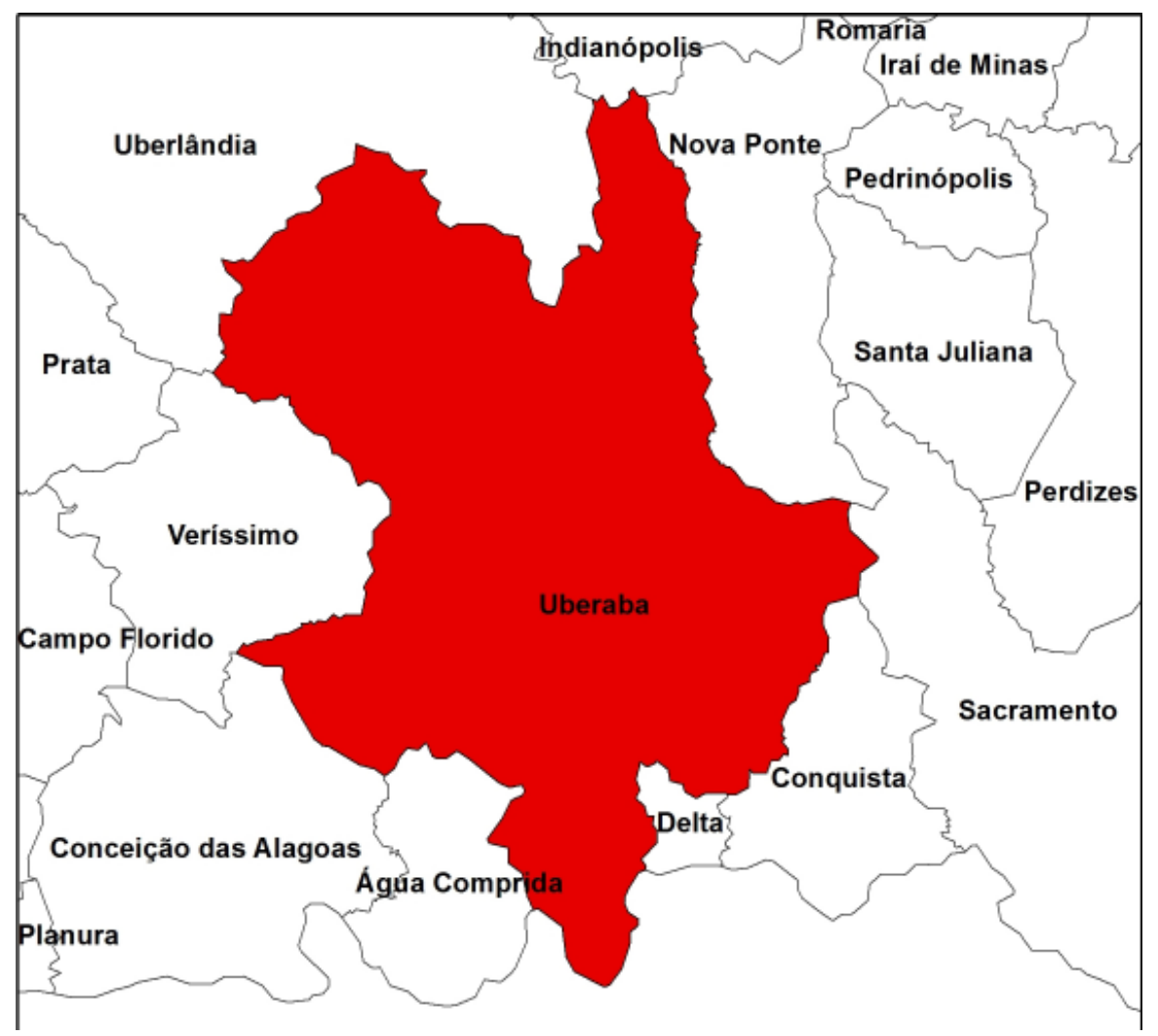


O Plano Diretor do município de Uberaba (Lei n. 359/2006) define ZEIS como "as áreas públicas ou privadas destinadas prioritariamente ao atendimento qualificado da habitação de interesse social para a população". Essa Lei determina que as ZEIS têm por finalidade a regularização urbanística e fundiária e a definição de parâmetros e critérios diferenciados para o parcelamento e a ocupação do solo, desde que garantido o saneamento básico, a instalação das redes de serviços urbanos e os equipamentos sociais necessários.

Esse plano diretor também indica que as prioridades para o desenvolvimento de programas e ações nas Zonas Especiais de Interesse Social serão definidas no processo de planejamento dos programas habitacionais a serem implementados. A Lei faz uma diferenciação das ZEIS em dois tipos: ZEIS 1 e ZEIS 2.

As ZEIS 1 "correspondem a terrenos públicos e particulares já ocupados irregularmente pela população nos quais deverão ser promovidas ações de urbanização e de regularização fundiária." (artigo 172, Lei n. 359/2006)

O artigo 176 define os critérios para identificação das ZEIS 1, sendo que os assentamentos delimitados com essa tipologia podem estar situados: em áreas de risco, desde que as moradias possam ser recuperadas, urbanizadas e regularizadas; em áreas públicas ou de preservação ambiental já comprometidas pela ocupação e de fácil integração à malha urbana, desde que os moradores não estejam em situação de risco; em loteamentos irregulares ou clandestinos destinados à população de baixa renda, carentes de infraestrutura e equipamentos urbanos, melhorias habitacionais ou titularidade. Nessas zonas podem ser estabelecidos parâmetros específicos de urbanização, parcelamento, uso e ocupação do solo urbano.

As ZEIS 2 são definidas como "áreas vazias, subutilizadas ou não edificadas, destinadas à promoção da habitação de interesse social e ao atendimento de famílias com renda mensal de até 6 (seis) salários mínimos" (artigo 173, Lei n. 359/2006)

Essas Zonas Especiais de Interesse Social ainda se subdividem em duas categorias: ZEIS 2.A (próprias para ocupação de baixa densidade, com uso residencial unifamiliar) e ZEIS 2.B (próprias para ocupação de alta densidade, com uso residencial multifamiliar). Todos os tipos de ZEIS instituídos estão delimitados e registrados em um mapa anexo ao Plano Diretor.

Dos municípios analisados, constata-se que Uberaba tem uma melhor definição das ZEIS, compreendendo até mesmo uma divisão em tipos que vão além dos dois mencionados ao longo do trabalho (ZEIS de áreas vazias e ZEIS de áreas ocupadas destinadas à regularização). Além disso, a Lei estabelece para as áreas vazias uma faixa de renda que deve ser atendida, o que nenhum dos municípios analisados apresentou na legislação que instituiu as ZEIS. Sendo assim, percebe-se que em termos de legislação, o município está à frente dos demais.

\section{Panorama da instituição de ZEIS}

Para uma melhor visualização da situação das ZEIS na legislação dos municípios analisados, foi elaborado um quadro síntese dos resultados obtidos (Figura 8).

\section{Considerações finais}

O presente trabalho é fruto de uma pesquisa exploratória nas legislações municipais em seis cidades médias de Minas Gerais. Para esse estudo foram investigadas leis municipais de Zoneamento, Uso e Ocupação do Solo e Planos Diretores. Certas dificuldades foram encontradas na realização da pesquisa devido à forma de divulgação das leis nos "sites" das Prefeituras e das Câmaras Municipais, que não facilita a busca. Nesse sentido, destaca-se que apesar da exigência legal de publicidade da legislação ter sido cumprida, o acesso a essa pelo cidadão é prejudicada, pois em alguns casos é preciso conhecer previamente o número e ano de publicação da lei.

A partir dos resultados obtidos na pesquisa foi possível constatar que as cidades médias estudadas estão incorporando a ZEIS na legislação municipal, pois apenas em Governador Valadares o instrumento não é instituído, tendo sido somente definido e citado. Contudo, a demarcação precisa de áreas, com georreferenciamento definido em lei, por exemplo, não foi realizada em nenhuma dessas cidades. 


\begin{tabular}{|c|c|c|c|c|c|c|c|}
\hline Município & $\begin{array}{l}\text { Menção } \\
\text { às ZEIS na } \\
\text { legisla- } \\
\text { ção muni- } \\
\text { cipal }\end{array}$ & $\begin{array}{l}\text { Leis em que as ZEIS } \\
\text { são mencionadas }\end{array}$ & $\begin{array}{l}\text { Instituição } \\
\text { de ZEIS na } \\
\text { legislação } \\
\text { municipal }\end{array}$ & $\begin{array}{l}\text { Leis em que as } \\
\text { ZEIS são } \\
\text { instituídas }\end{array}$ & $\begin{array}{l}\text { Nome } \\
\text { dado às } \\
\text { ZEIS }\end{array}$ & $\begin{array}{l}\text { Tipos de ZEIS } \\
\text { instituídas }\end{array}$ & $\begin{array}{l}\text { Existência } \\
\text { de demar- } \\
\text { cação em } \\
\text { mapas }\end{array}$ \\
\hline $\begin{array}{l}\text { Governador } \\
\text { Valadares }\end{array}$ & Sim & $\begin{array}{l}\text { Programa Municipal } \\
\text { de Regularização } \\
\text { Urbanística e } \\
\text { Fundiária } \\
\text { (Lei n. 031/2001) } \\
\text { Plano Diretor } \\
\text { (Lei n. 095/2006) }\end{array}$ & Não & - & ZHIS & - & Não \\
\hline Ipatinga & Sim & $\begin{array}{c}\text { Plano Diretor } \\
\text { (Lei n. 2230/2006) }\end{array}$ & Sim & $\begin{array}{c}\text { Plano Diretor } \\
\text { (Lei n.2230/2006) }\end{array}$ & ZEIS & $\begin{array}{l}\text { ZEIS de regularização } \\
\text { fundiária e de áreas } \\
\text { vazias sem } \\
\text { diferenciação }\end{array}$ & Sim \\
\hline Divinópolis & Sim & $\begin{array}{c}\text { Plano Diretor } \\
\text { (Lei n. 060/2000) } \\
\text { Zoneamento } \\
\text { (Lei n. 2418/1988) }\end{array}$ & Sim & $\begin{array}{c}\text { Zoneamento } \\
\text { (Lei n. 2418/1988) }\end{array}$ & $\begin{array}{l}\text { Zonas } \\
\text { Espe- } \\
\text { ciais }\end{array}$ & $\begin{array}{l}\text { Z4 - ZEIS de } \\
\text { regularização } \\
\text { Fundiária } \\
\text { Z1 - Permite a } \\
\text { utilização como ZEIS } \\
\text { de áreas vazias, mas } \\
\text { não é exclusiva para } \\
\text { empreendimentos } \\
\text { de habitação. }\end{array}$ & Sim \\
\hline Sete Lagoas & Sim & $\begin{array}{l}\text { Plano Diretor } \\
\text { (Lei n.109/2006) }\end{array}$ & Sim & $\begin{array}{l}\text { Plano Diretor } \\
\text { (Lei n. 109/2006) }\end{array}$ & ZEIS & $\begin{array}{l}\text { ZEIS de regulariza- } \\
\text { ção fundiária }\end{array}$ & Sim \\
\hline $\begin{array}{l}\text { Ribeirão das } \\
\text { Neves }\end{array}$ & Sim & $\begin{array}{c}\text { Lei de Uso e } \\
\text { Ocupação do Solo } \\
\text { (Lei n. 037/2006) }\end{array}$ & Sim & $\begin{array}{c}\text { Lei de Uso e } \\
\text { Ocupação do } \\
\text { Solo } \\
\text { (Lei n. 037/2006) }\end{array}$ & $\begin{array}{l}\text { ZEIS } \\
\text { ZEU } \\
\text { Social }\end{array}$ & $\begin{array}{l}\text { ZEIS de Regulariza- } \\
\text { ção Fundiária } \\
\text { ZEIS de áreas vazias }\end{array}$ & Sim \\
\hline \multirow[t]{2}{*}{ Uberaba } & \multirow[t]{2}{*}{ Sim } & \multirow[t]{2}{*}{$\begin{array}{l}\text { Plano Diretor } \\
\text { (Lei n. 359/2006) }\end{array}$} & \multirow[t]{2}{*}{ Sim } & \multirow[t]{2}{*}{$\begin{array}{l}\text { Plano Diretor } \\
\text { (Lei n. 359/2006) }\end{array}$} & \multirow[t]{2}{*}{ ZEIS } & $\begin{array}{l}\text { ZEIS } 1 \text { - ZEIS de } \\
\text { Regularização } \\
\text { Fundiária } \\
\text { ZEIS 2A - ZEIS de } \\
\text { áreas vazias (baixa } \\
\text { densidade) }\end{array}$ & \multirow[t]{2}{*}{ Sim } \\
\hline & & & & & & $\begin{array}{l}\text { ZEIS 2B - ZEIS de } \\
\text { áreas vazias (alta } \\
\quad \text { densidade) }\end{array}$ & \\
\hline
\end{tabular}

Figura 8: Panorama da Implantação de ZEIS em Seis Cidades Médias de Minas Gerais. Fonte: Isabelle Oliveira Soares e co-autores.
Com a análise das leis dos seis municípios estudados foi possível identificar que ainda há uma barreira na demarcação de ZEIS de áreas vazias. A maior parte dos municípios estabelece como ZEIS áreas já ocupadas destinadas à regularização fundiária. Porém, é preciso destacar que as ZEIS de áreas vazias são essenciais para formar um "banco de terras" disponível aos assentamentos habitacionais para população de baixa renda. Nesse sentido, Ribeirão das Neves e Uberaba estão à frente das demais cidades, já que diferenciaram e demarcaram esse tipo de ZEIS. Uberaba ainda faz uma diferenciação do tipo de ocupação nas ZEIS de áreas vazias, o que pode tornar o instrumento mais eficaz.

Mesmo as ZEIS sendo ferramentas com grande potencial para viabilizar a solução do problema habitacional do Brasil, a demarcação de áreas para esse fim ainda é dificultada pelos inúmeros conflitos que gera entre os diferentes grupos que interferem na produção do espaço urbano. Sendo foco de disputas políticas, acaba sendo pouco utilizado, já que o poder legislativo e mesmo o poder executivo municipal, muitas vezes se omitem no enfrentamento do problema para evitar desgaste político.

Por causa disso, as áreas propícias a serem demarcadas como ZEIS acabam não sendo delimitadas, os tipos de ZEIS não são definidos e as normas urbanísticas diferenciadas e mais flexíveis ficam pendentes de aprovação no poder legislativo. Assim, um instrumento capaz de transformar a realidade desigual das cidades acaba sendo subutilizado e muitas vezes esquecido pelo governo municipal. 
Provavelmente essas dificuldades não são exclusivas de cidades grandes ou médias, o que indica ainda um grande desafio a ser enfrentado na instituição de ZEIS em todos os municípios brasileiros.

Neste estudo, mesmo tendo sido encontrados certos avanços no que diz respeito à legislação, é preciso ressaltar que o simples fato das ZEIS serem instituídas ou constarem diretamente no Plano Diretor com sua demarcação em mapa não garante a implementação do instrumento. Sendo assim, há necessidade de uma investigação detalhada acerca da utilização de ZEIS nessas cidades, para que possa ser realizado um diagnóstico mais preciso, o que indica novas possibilidades para pesquisas nesse campo.

\section{Referências bibliográficas}

ALFONSIN, B. de M. Dos instrumentos da Política Urbana. In: MATTOS, L.P. (org.). Estatuto da Cidade comentado. Belo Horizonte: Mandamento, 2002. (Capítulo II).

ANCONA, A. L. Caderno 5 - Zonas Especiais de Interesse Social In: SANTOS JUNIOR, O. A. dos; MONTANDON, D. T.(orgs.) Os planos diretores municipais pós Estatuto da Cidade: balanço crítico e perspectivas. Rio de Janeiro: Letra Capital/Observatório das Cidades/ IPPUR/UFRJ, 2011.

AMORIM FILHO, Oswaldo Bueno; RIGOTTI, José Irineu Rangel. Os limiares demográficos na caracterização das cidades médias. Encontro da Associação Brasileira de Estudos Populacionais, 13., 2002, Ouro Preto, Anais... Ouro Preto, 2002. Disponível em <http://150.161.23.3/arquivos/bibliografia/os\%20 limiares \%20demogr \%C3\%A 1ficos\%20na \% 20 caracteriza\%C3\%A7\%C3\%A3o.pdf>. Acesso em: 10 ago. 2011.

AMORIM FILHO, Oswaldo Bueno; RIGOTTI, José Irineu Rangel; CAMPOS, Jarvis. Os níveis hierárquicos das cidades médias de Minas Gerais. Revista RA'E GA - O Espaço Geográfico em Análise. n.13, p. 7-18. Curitiba: Ed. UFPR, 2007. Disponível em: <ojs.c3sl.ufpr.br/ ojs2/index.php/raega/article/download/7784/9076>. Acesso em: Acesso em: 10 ago. 2011.

BALTRUSIS, Nelson. Instrumentos urbanísticos e o acesso à terra urbana em Diadema: o caso das AEIS. Ambiente Construído, v. 3, n.4, 2003. Disponível em <http://seer.ufrgs.br/ambienteconstruido/ article/view/3507/1906>. Acesso em 15 de maio de 2011.

BRASIL. Lei n. 10.257, de 10 de julho de 2001. Regulamenta os artigos da Constituição Federal, estabelece diretrizes gerais da política urbana e dá outras providências. Diário Oficial da União. Brasília, 11 jul. 2001.

. Lei n. 6.766, de 19 de dezembro de 1979. Dispõe sobre o parcelamento do solo urbano e dá outras providências. Diário Oficial da União. Brasília, 20 dez. 1979.
Lei n. 9.785, de 29 de janeiro de 1999. Altera o Decreto-Lei no 3.365, de 21 de junho de 1941 (desapropriação por utilidade pública) e as Leis nos 6.015, de 31 de dezembro de 1973 (registros públicos) e 6.766 , de 19 de dezembro de 1979 (parcelamento do solo urbano). Diário Oficial da União. Brasília, 01 fev 1999. Retificado em 04 fev. 1999.

CALDAS, N. M. P. Os novos instrumentos da política urbana: alcance e limitações das ZEIS. Tese de Doutorado - Faculdade de Arquitetura e Urbanismo/USP. São Paulo, 2009

CAIXA Econômica Federal. Demanda habitacional no Brasil. Brasília: CAIXA, 2011.

DIAS, Solange Gonçalves. Regularização fundiária em Zonas de Especial Interesse Social. Revista Integração. Abril/maio/junho 2008, Ano XIV, n. 53, 143-149.

DIVINÓPOLIS, Lei n. 2.418 de 18 de novembro de 1988. Estabelece normas de uso e ocupação do solo no Município de Divinópolis. Disponível em: <http:// www.jusbrasil.com.br/legislacao/ 604766/lei-241888-divinopolis-mg> Acesso em: 26 mai 2011.

DIVINÓPOLIS, Lei n. 60 de 24 de março de 2000. Institui o Plano Diretor do Município de Divinópolis e dá outras providências. Disponível em: <http://www.jusbrasil. com.br/legislacao/614622/lei-complementar-60-00divinopolis-mg> Acesso em: 26 mai 2011.

FERNANDES, E. Perspectivas para a renovação das políticas de legalização de favelas no Brasil. In: ABRAMO, Pedro. (org.) A cidade da Informalidade. O desafio das cidades latino-americanas. Rio de Janeiro: Sette Letras, FAPERJ, 2003.

GOVERNADOR VALADARES, Lei n. 031 de 27 de abril de 2001. Dispõe sobre o programa Municipal de Regularização Urbanística e Fundiária e dá outras providências. Disponível em: <http://www.camaragv. mg.gov.br/upload/legislacao/\%7B77CFA4CB-5ABO401A-B45A-2DE4F567E77 D\%7D.pdf> Acesso em: 26 mai 2011.

GOVERNADOR VALADARES. Lei n. 095, de 27 de dezembro de 2006. Institui o Plano Diretor de Desenvolvimento do Município de Governador Valadares - Minas Gerais e dá outras providências. Disponível em: <http://www.camaragv.mg.gov. br/upload/legislacao/\%7B2C983C8A-246E-46E4-A69F-FF4ABE3FFE56\%7D.pdf> Acesso em: 26 mai 2011.

IBGE. Instituto Brasileiro de Geografia e Estatística. Disponível em: <http://ibge.gov.br/home/>. Acesso em: 19 jun. 2011.

Regiões de influência das cidades - 2007. Rio de Janeiro: IBGE, 2008. Disponível em <ftp://geoftp. ibge.gov.br/Regic/regic.zip>. Acesso em: 08 ago. 2011.

IPATINGA. Lei n. 2230, de 06 de outubro de 2006. Institui o Plano Diretor do Município de Ipatinga. Disponível em: <http://www.camaraipatinga.mg.gov.br/cmi v5/ detalnorma.php?idnorma=6873> Acesso em: 26 mai 2011.

IPEA, 2008. População e PIB das cidades médias crescem mais que no resto do Brasil. [on line] Disponível em: <http://www.ipea.gov.br/sites/000/2/ pdf_release/32_release_PIBdascidades.pdf $>$. Acesso em: 27 jun. 2011. 
MIRANDA, L.; MORAES, D. O Plano de Regularização das Zonas Especiais de Interesse Social (Prezeis) do Recife: democratização da gestão e planejamento participativo. In: CARDOSO, A. L. (coord.). Habitação social nas metrópoles brasileiras - uma avaliação das políticas habitacionais em Belém, Belo Horizonte, Porto Alegre, Recife, Rio de Janeiro e São Paulo no final do século XX. Coleção Habitare. Porto Alegre: ANTAC, 2007. Cap. 11.

RIBEIRÃO DAS NEVES. Lei n. 037 de 9 de outubro de 2006. Dispõe sobre normas de Uso e Ocupação do Solo no Município de Ribeirão das Neves. Disponível em: <http://www.neves.mg.gov.br/images/stories/ Secretarias/Planejamento/lei_complementar_0372006_uso_e_ocupacao_o_do_solo.pdf> Acesso em: 26 mai 2011

ROLNIK, R. (org.). Como produzir moradia bem localizada com os recursos do programa minha casa minha vida? implementando os instrumentos do Estatuto da Cidade. [on-line]. Brasília, Ministério das Cidades, 2010. Disponível em <http://web.observatoriodasmetropoles.net/planosdiretores/download/ cartilha. pdf> Acesso em: 5 nov. 2010.

Zona Especial de Interesse Social. Fundação Perseu Abramo: 2006. [on line] Disponível em <http://www2.fpa.org.br/formacao/pt-no-parlamento/textos-e-publicacoes/zona-especial-de-interessesocial>. Acesso em: 26 mai. 2011.

ROLNIK, R.; CYMBALISTA, R.; NAKANO, K. Solo Urbano e habitação de interesse social: a questão fundiária na política habitacional e urbana do país. 2002. [on-line] Disponível em <http://www.usp.br/srhousing/rr/docs/ solo_urbano_e_habitacao_de_interesse_social.pdf > Acesso em: 10 mar. 2011.
SANTOS, R. M. dos. Legislação e localização: as Zonas Especiais de Interesse Social (ZEIS) no município de Itajaí, SC. Dissertação (Mestrado em Urbanismo, História e Arquitetura da Cidade). Programa de PósGraduação em Urbanismo, História e Arquitetura da Cidade - PGAU-Cidade. Florianópolis, 2010.

SANTOS JUNIOR, O. A. dos; MONTANDON, D. T. (orgs.) Os planos diretores municipais pós Estatuto da Cidade: balanço crítico e perspectivas. Rio de Janeiro: Letra Capital/ Observatório das Cidades IPPUR/ UFRJ, 2011.

SAULE JÚNIOR. N. et al. As Zonas Especiais de Interesse Social como instrumento da política de regularização fundiária. Fórum de Direito Urbano e Ambiental, n 30 , novembro de 2006, p. 3762-73.

SETE LAGOAS. Lei n. 109 de 9 de outubro de 2006 Promove a Revisão do Plano Diretor do Município de Sete Lagoas. Disponível em: <http://www.setelagoas.mg.gov.br/pref-arquivos_pdf/leicom109.pdf>. Acesso em: 26 mai. 2011.

SPINOLA, R. M. G. ZEIS: o Interesse Social das Zonas Especiais para a habitação popular, aplicadas ao município de Santos/SP. Dissertação Mestrado - Escola Politécnica / USP. São Paulo,2010.

UBERABA. Lei n. 359 de 11 de outubro de 2006. Institui o Plano Diretor do Município de Uberaba e dá outras providências. Disponível em: <http://www.uberaba. mg.gov.br/portal/acervo/plano_diretor/arquivos/ legislacao_urbanistica

_vigente/lei_complementar_359/lei_complementar_359. pdf>. Acesso em: 26 mai. 2011 